\title{
TRADISI BIMBANG BEBALAI PADA ETNIS SERAWAI: SEBUAH ANALISIS FUNGSIONAL STRUKTURAL
}

\author{
BIMBANG BEBALAI TRADITION \\ AMONG THE SERAWAI: A STRUCTURAL FUNCTIONAL \\ ANALYSIS
}

\author{
Rois Leonard Arios \\ Balai Pelestarian Nilai Budaya Sumatra Barat \\ Jl. Raya Belimbing No.16A Kuranji, Padang, Indonesia \\ rolear72@yahoo.co.id
}

Diterima tanggal 28 Juni 2020

Disetujui tanggal 23 November 2020

\begin{abstract}
Tradition of an ethnic group will still exist and be sustainable if the supporting community continues to carry out its role in accordance with its function in the tradition. This paper explains how bimbang bebalai tradition in the Serawai tribe, which could be implemented during the reign, is no longer carried out even though it has been facilitated by the government. In analyzing the problem, the A.R. Radcliffe-Brown structural functional approach was used by focusing on the analysis of the role functions of each structure. The study was conducted with a qualitative approach with interviews and observations as a primary data collection tool and supported by literature study. The study has found that bimbang bebalai tradition cannot be implemented at this time because the existing role of indigenous institution and structure in the tradition itself does not work. The role of the government that is overboard actually eliminates the community's role which is supposed to be facilitated as the owner and executor of the tradition.
\end{abstract}

Keywords : bimbang bebalai, structural functional, Serawai, role and function.

\begin{abstract}
ABSTRAK
Tradisi pada suatu suku bangsa akan tetap eksis dan lestari jika masyarakat pendukungnya tetap menjalankan peran sesuai dengan fungsinya pada tradisi tersebut. Tulisan ini menjelaskan bagaimana tradisi bimbang bebalai pada suku bangsa Serawai yang pada masa pemerintahan tradisional bisa dilaksanakan tetapi saat ini tidak lagi dilaksanakan walaupun sudah difasilitasi oleh pemerintah. Dalam menganalisis masalah, pendekatan teori fungsional struktural A.R. Radcliffe-Brown digunakan dengan berfokus pada analisis fungsi peran setiap struktur. Penelitian dilakukan dengan pendekatan kualitatif dengan wawancara dan pengamatan sebagai alat pengumpul data utama dan didukung dengan studi pustaka. Dari hasil analisis ditemukan bahwa tradisi bimbang bebalai tidak bisa dilaksanakan pada saat ini karena peran lembaga adat dan struktur yang ada pada tradisi itu tidak berfungsi. Peran pemerintah yang terlalu
\end{abstract}


luas justru menghilangkan peran masyarakat yang seharusnya difasilitasi sebagai pemilik dan pelaksana tradisi tersebut.

Kata kunci: bimbang bebalai, fungsional struktural, Serawai, peran dan fungsi.

\section{A. PENDAHULUAN}

Suku bangsa di Provinsi Bengkulu mengacu pada Depdikbud (1978) terdiri atas lima suku bangsa yaitu Rejang, Bengkulu, Serawai, Lampung, dan Pasemah. Wilayah kebudayaan Serawai digambarkan berada di Kabupaten Bengkulu Selatan. Namun beberapa penelitian lainnya justru menggambarkan bahwa terdapat sepuluh suku bangsa sebagai penduduk asli di Provinsi Bengkulu. Penelitian tersebut antara lain terkait dengan suku bangsa Rejang (Arios dan Yondri 2007), suku bangsa Enggano (Arios 2004), suku bangsa Kaur (Arios 2012), suku bangsa Mukomuko (Sarwono et al. 2005), suku bangsa Pasemah/Besemah (Refisrul 2019), suku bangsa Serawai (Sarwono dan Purwadi 2017; Octaviani 2017), suku bangsa Pekal (Yondri, Arios, dan Jumhari 2004), Melayu Bengkulu, suku bangsa Lembak (Arios 2017), dan Semende.

Suku bangsa Serawai mendiami hampir seluruh wilayah bagian selatan Provinsi Bengkulu yang terdiri dari Kabupaten Seluma, Kabupaten Bengkulu Selatan, dan sebagian Kabupaten Kaur. Beberapa tulisan yang terkait dengan sejarah Serawai seperti Dali (2004) belum bisa menyimpulkan sejarah asal-usul karena kurangnya bukti-bukti pendukung baik berupa artefak maupun sumber tertulis lainnya. Namun budaya Serawai memiliki kedekatan budaya dengan budayabudaya di sekitarnya seperti Melayu Bengkulu dan Besemah di Kota Pagaralam.

Salah satu tradisi pada suku bangsa Serawai adalah yang terkait dengan adat perkawinan. Salah satu proses adat perkawinan Serawai adalah tradisi bimbang bebalai, yaitu tradisi yang mengumpulkan tiga sampai lima pasang pengantin yang disepakati menikah pada waktu yang bersamaan. Pernikahan bisa juga dilaksanakan dalam rentang waktu tertentu seperti satu minggu di satu desa atau desa lainnya untuk mengikuti proses bimbang bebalai yang diselenggarakan oleh masyarakat dalam satu desa atau dusun (Pemerintah Kabupaten Seluma 2014).

Para pengantin dalam prosesi bimbang bebalai dikumpulkan dalam satu balai yang dibangun oleh masyarakat (mato gawe) untuk kepentingan acara ini. Acara dihadiri oleh unsur lembaga adat, rajo penghulu (imam balai) sebagai pemimpin acara, tokoh masyarakat, perwakilan pemerintah (kepala desa, camat, maupun dari tingkat kabupaten), muda mudi (memudo), dan mak inang (ibuibu sebagai pengawas memudo). Masyarakat desa atau dusun (mato gawe) sebagai pelaksana kegiatan membangun balai sebagai tempat acara, memotong kerbau, dan memasak nasi 
sebagai hidangan untuk seluruh yang hadir.

"Acara diisi dengan pemberian nasihat kepada para pengantin oleh masing-masing unsur masyarakat yang hadir, makan bersama, dan acara hiburan berupa tari Ulu, tari Khalifa, syarafal anam, dan dendang Melayu. Pada akhir acara, mato gawe sebagai pelaksana acara akan mendapat pembagian khusus berupa kepala kerbau yang dipotong, sebagai penghargaan atas jerih payah bimbang bebalai," jelas Subur dan Bustan A. Dali pada 13 Februari 2019.

Pelaksanaan tradisi bimbang bebalai melibatkan masyarakat luas dalam satu dusun (desa) dan dusun (desa) tetangga sehingga bukan sekadar prosesi yang dilaksanakan oleh satu keluarga inti atau keluarga luas. Jika ada yang menikah, maka harus ada kesepakatan antara tokoh adat di kampung tersebut (berasan) untuk menentukan hari yang tepat, yang jadwalnya disesuaikan dengan keluarga lainnya yang juga akan menikahkan anak mereka. Proses ini menggambarkan adanya kebersamaan warga dalam pelaksanaan bimbang.

Sebuah tradisi dalam satu suku bangsa bisa terlaksana jika setiap unsur dalam masyarakat tersebut melaksanakan fungsi sesuai dengan perannya di dalam tradisi tersebut. Peran-peran yang ada diatur oleh norma-norma sebagai sebuah sistem yang menghubungkan seluruh unsur sehingga tradisi tersebut dapat dilaksanakan.
Secara ideal, berfungsinya peranperan yang ada pada masyarakat akan membuat sebuah tradisi tetap eksis di masyarakat, apalagi jika mendapat dukungan pemerintah dengan diterbitkannya peraturan daerah. Namun tradisi bimbang bebalai justru tidak bisa dilaksanakan dan sudah tidak diketahui oleh sebagian warga suku bangsa Serawai. Tujuan penelitian ini adalah untuk menganalisis dengan menggunakan pendekatan teori fungsional struktural tradisi bimbang bebalai yang pernah dilaksanakan oleh masyarakat. Tujuan lainnya adalah untuk mengetahui upaya pemerintah dalam rangka mengangkat kembali dan melestarikan tradisi tersebut agar dikenal dan dilaksanakan oleh masyarakat.

Melalui penelusuran literatur, belum ditemukan tulisan yang membahas tradisi bimbang bebalai kecuali yang terdapat dalam Kompilasi Hukum Adat di Kabupaten Seluma (Pemerintah Kabupaten Seluma 2014). Namun tulisan yang membahas budaya Serawai, terutama adat perkawinannya, sudah cukup banyak. Tulisan-tulisan tersebut masih sebatas menggambarkan tradisi perkawinan yang lazim dilaksanakan pada masa sekarang dan tema-tema tentang kesenian pada tradisi perkawinan. Dengan demikian pembahasan tentang tradisi bimbang bebalai merupakan isu baru yang penting untuk diketahui oleh masyarakat.

Beberapa tulisan yang terkait dengan budaya Serawai dan dijadikan 
Handep Jurnal Sejarah dan Budaya Vol. 4, No. 1, Desember 2020, hlm. 87-110

rujukan dalam tulisan ini adalah tulisan Dihamri (2017) yang mendeskripsikan tradisi daur hidup suku bangsa Serawai mulai dari kehamilan, lahir, sunat, dan perkawinan. Namun tidak disebutkan adanya tradisi bimbang bebalai, meskipun ada beberapa tahapannya yang sama dengan proses pelaksanaan bimbang bebalai.

Tulisan Fitriani (2019) adalah tentang deskripsi dan penggunaan tari Napa pada suku bangsa Serawai namun tidak menyinggung adanya konsep tradisi bimbang bebalai. Dua tulisan berikut, yakni tulisan Arief (2018) dan Viadinata (2016), mendeskripsikan secara detail tentang tari Andun pada adat perkawinan suku bangsa Serawai. Sebagian penjelasan yang ada di kedua tulisan tersebut relevan dengan tahapan pelaksanaan bimbang bebalai, terutama pada aspek kesenian, walaupun tetap tidak ditemukan konsep bimbang bebalai. Sedangkan tulisan Sarwono (2017) lebih berfokus pada kajian tentang rejung melalui naskah kuno. Sebagian konsep yang ada di dalam tulisan Sarwono dipakai dalam tulisan ini.

Secara konseptual, kebudayaan bersifat universal karena seluruh suku bangsa memiliki unsur-unsur kebudayaan dengan kekhasan masingmasing. Setiap unsur kebudayaan tersebut memiliki tiga wujud yaitu sistem ide atau gagasan atau norma, sistem tindakan atau perilaku, dan wujud kebendaan (Koentjaraningrat 2013:150). Dalam penerapannya sehari-hari, unsur kebudayaan tersebut dilaksanakan oleh orang-orang yang memiliki peran masing-masing sesuai dengan status sosial yang melekat pada orang tersebut.

Analisis kebudayaan oleh Radcliffe-Brown menganalogikan masyarakat atau sebuah suku bangsa sebagai organisme tubuh manusia. Organisme tubuh manusia terdiri dari berbagai macam unsur seperti cairan, sel-sel, dan organ-organ tubuh lainnya yang saling berhubungan sehingga membentuk satu kesatuan organisme. Unsur-unsur pembentuk organisme tersebut merupakan satu kesatuan yang terintegrasi sebagai sistem hubungan yang mengikat seluruh unsur tersebut. Sistem hubungan inilah yang disebut oleh Radcliffe-Brown sebagai struktur organisme. Selama hidup, struktur tersebut akan selalu menjaga keseimbangan. Dengan demikian jika terjadi pergantian sel atau cairan, susunan struktur tidak akan berubah. Adanya kehidupan merupakan tanda berfungsinya unsur-unsur dalam organisme tersebut. Fungsi dari unsurunsur tersebut adalah peranan yang dimainkan atau kontribusi setiap unsur dalam menunjang kehidupan organisme (Radcliffe-Brown 1952:7887). Sebagai contoh, fungsi jantung sebagai pemompa darah ke seluruh tubuh, atau fungsi perut sebagai pengolah makanan menjadi zat-zat yang dibutuhkan oleh tubuh. Dengan berfungsinya seluruh peran, maka organisme akan hidup. Demikian juga sebaliknya jika salah satu unsur tidak berfungsi maka organisme tersebut 
akan bermasalah dan bisa mati (Marzali 2014:34-35; Koentjaraningrat 1987:180-182).

Terkait dengan tradisi bimbang bebalai pada suku bangsa Serawai, unsur pembentuk tradisi ini terdiri atas pengantin, unsur lembaga adat, imam balai sebagai pemimpin acara, tokoh masyarakat, perwakilan pemerintah (kepala desa, camat, atau dari tingkat kabupaten), muda mudi (memudo), mak inang (ibu-ibu sebagai pengawas memudo), mato gawe (anggota masyarakat di desa atau dusun sebagai panitia), dan pemain musik. Mengacu pada pemikiran dari Radcliffe-Brown (1952:78-87), seluruh unsur tersebut terintegrasi menjadi sebuah struktur yang menjalankan fungsinya sehingga tradisi tersebut dapat berjalan. Artinya siapapun pengantinnya atau siapapun orang yang berada pada struktur tersebut harus menjalankan fungsinya. Dengan demikian harus dijelaskan fungsi dari masing-masing struktur tersebut. Fungsi dari masing-masing struktur tersebut harus sesuai dengan perannya menurut norma-norma yang telah disepakati bersama oleh suku bangsa Serawai. Dengan menjelaskan fungsi dari struktur tersebut, maka proses pelaksanaan tradisi bimbang bebalai dapat dideskripsikan sekaligus dianalisis untuk mengetahui kemungkinan adanya perubahan fungsi pada struktur.

Model analisis fungsional struktural Radcliffe-Brown sangat relevan digunakan dalam menganalisis keberlangsungan kebudayaan atau dalam upaya pelestarian sebuah kebudayaan, khususnya tradisi bimbang bebalai. Inti pemikiran RadcliffeBrown adalah bahwa setiap kebiasaan atau kepercayaan (tradisi) pada sebuah masyarakat memiliki fungsi tertentu untuk melestarikan struktur masyarakat tersebut sehingga masyarakat tersebut bisa lestari (Haviland 1999:335).

\section{B. METODE}

Penelitian ini menggunakan pendekatan kualitatif yang bersifat holistisintegratif, thick description, dan dengan analisis deskriptif kualitatif (Spradley 1997). Pendekatan kualitatif dipilih karena mampu menganalisis proses-proses sosial dan makna yang terdapat pada fenomena yang tampak di permukaan. Penelitian ini bukan hanya menjelaskan fakta tetapi juga proses dan makna di balik fakta tersebut (Bungin 2011:68). Metode ini juga dapat dipakai untuk memahami makna di balik fenomena yang belum diketahui dan memantapkan wawasan terhadap sesuatu yang baru atau yang masih sedikit diketahui (Corbin dan Strauss 2008:32).

Pengumpulan data dilakukan melalui studi pustaka, wawancara, dan pengamatan terhadap kehidupan sosial dan lingkungan alam lokasi penelitian. Data lapangan selanjutnya divalidasi dan dianalisis untuk menjawab permasalahan dan tujuan penelitian (Afrizal 2014:116).

Proses wawancara diawali dengan menemui Kepala Bidang Kebudayaan Dinas Pendidikan dan Kebudayaan 
Handep Jurnal Sejarah dan Budaya Vol. 4, No. 1, Desember 2020, hlm. 87-110

Kabupaten Seluma yang secara administratif memiliki wewenang di bidang kebudayaan. Melalui wawancara tersebut diperoleh informan berikutnya yaitu Bustan A. Dali. Beliau adalah seorang tokoh adat, memiliki pengetahuan tentang sejarah Serawai, serta menulis beberapa buku terkait budaya dan sejarah Serawai. Informan penelitian berjumlah tujuh orang yang ditelusuri melalui sistem snowball. Mereka mewakili tokoh adat, penulis, dan unsur pemerintah.

Data yang telah dikumpulkan selanjutnya dianalisis dengan langkahlangkah yang disebutkan oleh Spradley (1997) yaitu proses analisis domain (memisahkan data yang relevan dengan permasalahan dan tujuan penelitian), selanjutnya dilakukan analisis taksonomi yaitu dengan memperdalam data awal (domain). Tahap berikutnya adalah analisis komponen, yaitu mencari persamaan dan perbedaan komponen yang telah dikumpulkan sehingga ditemukan spesifikasi data sesuai tujuan penelitian melalui wawancara, observasi, maupun studi pustaka. Tahap terakhir adalah analisis tema budaya, yaitu merumuskan benang merah sehingga diperoleh jawaban pertanyaan penelitian.

\section{HASIL DAN BAHASAN}

Suku bangsa Serawai mendiami wilayah Kabupaten Bengkulu Selatan, sebagian Kabupaten Kaur, dan Kabupaten Seluma di Provinsi Bengkulu. Secara pasti belum ada sumber tertulis yang menyebutkan asal- usul suku bangsa Serawai. Pendapat Dali Yazid seperti yang dikutip oleh Arief (2018:7) menyebutkan bahwa menurut cerita yang disampaikan secara turun-temurun, nama Serawai berasal dari kata sauaai yang diartikan sebagai sebuah bukit pemisah antara dua sungai, yaitu Sungai Musi dan Sungai Seluma.

Tulisan lainnya ada juga yang menghubungkan suku bangsa Serawai sebagai bagian dari suku bangsa Besemah di Kota Pagaralam Provinsi Sumatra Selatan yang merantau ke wilayah selatan Provinsi Bengkulu. Hal ini juga didukung oleh letak geografis yang berdekatan dan beberapa kedekatan atribut budaya (Arios 2014; Arios 2019).

\section{Konsep dan Sejarah Bimbang Bebalai}

Kegiatan bimbang (pesta adat) pada suku bangsa Serawai sangat terkait dengan pertanian. Pada saat akan memasuki musim panen, biasanya sebuah keluarga sudah bisa merencanakan bimbang sesuai dengan kebutuhannya, seperti menikahkan anak. Acara bimbang umumnya dilakukan setelah selesai proses panen di sawah. Hasil panen tersebut sebagian disisihkan oleh masyarakat sebagai modal untuk kegiatan sosial termasuk untuk kepentingan bimbang bebalai.

Proses menikahkan anak diawali dengan madurasan (pertunangan) yang dilaksanakan sebelum masa panen padi tiba. Pada kesempatan ini pula, pihak keluarga laki-laki dan perempuan 
bermusyawarah untuk menyepakati bentuk bimbang adat yang akan dipakai. Hasil kesepakatan ini akan disampaikan ke depati atau pasirah yang ada di dusun mereka masing-asing atau ke ketua adat desa.

Tradisi bimbang bebalai merupakan salah satu jenis adat perkawinan pada suku bangsa Serawai yang terbesar dan terlengkap dibandingkan dengan dua jenis adat perkawinan lainnya, yaitu bimbang Melayu dan bimbang cara Malin. Bimbang bebalai merupakan perpaduan adat perkawinan Melayu dan Malin yang dilaksanakan selama beberapa hari dengan melibatkan seluruh masyarakat di dusun penyelenggara dan dusun tetangga.

Jika dilihat dari sejarahnya, tidak diketahui pasti kapan bimbang bebalai mulai dilaksanakan di masyarakat. Pada masa kolonial Belanda istilah bimbang bebalai tidak dikenal. Pada masa ini hanya dikenal tiga jenis adat bimbang pada suku bangsa Serawai di wilayah Onderafdeling Seloema yaitu: bimbang cara Melayu, bimbang cara Ulu, dan bimbang cara Malin (Hoesin 1938:58-59). Namun dari pengalaman para informan, sebagai muda mudi mereka sudah terlibat sebagai pelaksana bimbang bebalai dan terakhir yang pernah diikuti adalah pada 1960an (wawancara dengan Jamahari, 21 Juli 2019 di Sukaraja; wawancara dengan Zairin Rasul, 24 Juli 2019 di Kota Bengkulu).
"Syarat utama untuk dapat melaksanakan tradisi bimbang bebalai adalah harus membangun balai (teratak), memotong kerbau, dan ada pengantin (bunting dan penganten) ${ }^{1}$. Tidak ada keharusan tradisi bimbang bebalai hanya dapat dilaksanakan jika ada lebih dari satu pasang pengantin, tetapi tergantung pada kemampuan keluarga pihak laki-laki atau perempuan," ujar Jamahari di Sukaraja pada 21 Juli 2019. Hal ini berbeda dengan konsep yang dibuat Pemerintah Kabupaten Seluma bahwa tradisi bimbang bebalai bisa dilaksanakan jika terdapat tiga pasang pengantin atau lebih (Pemerintah Kabupaten Seluma 2014).

Bustan A. Dali, di Tais pada 20 Juli 2020 menjelaskan bahwa balai yang dibuat merupakan hasil gotong royong seluruh warga dusun. Pada zaman dahulu kegiatan ini diatur oleh pasirah dan depati ${ }^{2}$ baik pembagian kerja maupun pengumpulan bahan.

Balai adalah suatu bangunan yang cukup besar dengan konstruksi berbahan baku lokal. Ukuran balai 20 meter x 30 meter, berbentuk bangunan memanjang dengan bahan konstruksi

\footnotetext{
${ }^{1}$ Bunting adalah sebutan untuk pengantin wanita dalam bahasa Serawai dan penganten adalah sebutan untuk pengantin pria.

2 Pasirah adalah pemimpin suatu wilayah administratif yang disebut marga (saat ini identik dengan desa walaupun tidak sesederhana desa karena cakupan kekuasaan pasirah menyangkut urusan pemerintahan dan adat). Adapun depati adalah pemimpin administratif dan budaya di tingkat dusun (setingkat rukun warga saat ini).
} 
terdiri atas kayu bulat dan bambu. Konstruksi atap dibuat dari daun puar (sejenis tumbuhan hutan) atau daun kelapa yang disemat (dirakit) sedemikian rupa. Dindingnya terbuat dari daun puar atau anyaman daun kelapa. Hiasan pada bagian luar terbuat dari daun kelapa yang masih muda (janur), sedangkan hiasan pada bagian dalam adalah kekirai yaitu kain merah dan kuning yang disulam manik-manik dan ornamen khas lainnya. Kekirai dipasang di pelaminan pengantin dan tempat permusyawaratan adat atau undangan khusus. Di tengah bangunan dipasang obor yang akan digunakan sebagai kebung penarian, tempat pergelaran tarian muda mudi dan tari Kelipa (wawancara dengan Bustan A. Dali di Tais pada 20 Juli 2019).

Pembangunan balai diawali dengan penyembelihan seekor kerbau, sebagian dagingnya dikonsumsi para pekerja dan sebagiannya lagi dibagi-bagikan kepada warga dusun. Proses pembangunan balai dimulai di pagi hari dan biasanya bangunan selesai dikerjakan sekitar pukul 17.00 WIB. Selama proses pembangunan balai ini disuguhkan beraneka macam makanan tradisional. Kopi, dan bubur yang terbuat dari tepung beras (bubur kerikil) dihidangkan untuk sarapan para pekerja. Kue-kue tradisional berupa lepat, cucur bandan, dan lain-lain disediakan sekitar pukul 09.00 WIB. Selanjutnya gulai daging kerbau dihidangkan sekitar pukul 12.00 WIB saat acara makan siang bersama para pekerja yang membangun balai dan warga yang terlibat. Hidangan berupa kue dan kopi dihidangkan lagi sekitar pukul 15.00 WIB.

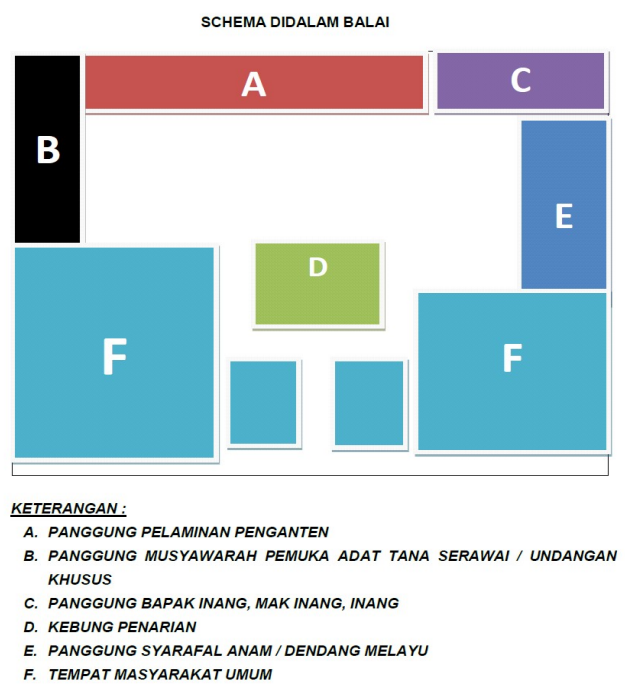

Gambar 1. Skema pembagian ruang balai. Sumber: Wawancara dengan Bustan A. Dali di Tais pada 20 Juli 2019.

\section{Pelaksanaan Tradisi Bimbang Bebalai}

Salah satu tujuan dari kegiatan tradisi bimbang bebalai adalah untuk menjalin silahturahmi antaranggota masyarakat di dusun, antara masyarakat di dusun penyelenggara dengan dusun tetangga, dan di kalangan muda mudi di sekitar daerah tersebut. Tujuan lainnya adalah agar pasangan pengantin mendapat berkah dari seluruh warga.

Tradisi bimbang bebalai idealnya dapat dilakukan oleh satu keluarga besar di satu dusun. Namun karena biaya yang dibutuhkan cukup besar, maka tradisi ini bisa dilakukan oleh beberapa pasangan pengantin secara bersama-sama, baik yang berasal dari satu dusun yang sama maupun dusun yang berbeda. 
Pada masa dahulu, tahapan tradisi bimbang bebalai diawali dengan musyawarah internal keluarga luas pihak yang akan melakukan bimbang untuk menyepakati apakah akan mengadakan tradisi bimbang bebalai atau hanya sekadar bimbang sepagi (perayaan pernikahan hanya berupa resepsi yang dilaksakan satu hari tanpa mengikuti proses adat lengkap). Pertimbangan utamanya adalah terkait dengan pembiayaan yang cukup besar yang harus disiapkan untuk pelaksanaan bimbang bebalai, antara lain untuk penyediaan seekor kerbau, pembangunan balai dan bermacammacam kebutuhan lain untuk tiga hari atau lebih pelaksanaan kegiatan.

Kesepakatan keluarga tersebut selanjutnya disampaikan ke ketua adat di dusun (depati) yang selanjutnya akan disampaikan ke pasirah untuk mendapatkan persetujuan. Selanjutnya pasirah akan memerintahkan depati menjadi ketua panitia pelaksana dan merancang seluruh proses pelaksanaan kegiatan. Setelah mendapat persetujuan dari pasirah, biasanya dibutuhkan waktu minimal satu bulan untuk melakukan persiapan.

Selanjutnya depati mengumpulkan warga dusun untuk melakukan musyawarah (beijau) pembagian tugas mulai dari yang bertugas mencari bahan untuk membangun balai (kayu, rotan, dan lain-lain), bertugas memasak, dan tugas-tugas lainnya yang dianggap perlu. Muda mudi dusun penyelenggara biasanya bertugas mengundang muda mudi dusun tetangga dengan membawa tanda (berupa sirih). Tanda tersebut berasal dari depati dusun mereka yang akan diberikan kepada depati dusun tetangga. Hal ini dilakukan agar depati dusun tetangga mengizinkan mereka untuk bertemu dan mengundang muda mudi dusun tersebut. ${ }^{3}$

Bahan yang dibutuhkan untuk pembangunan balai adalah kayu, bambu, dan atap yang terbuat dari daun kelapa. Seluruh bahan-bahan tersebut dikumpulkan oleh warga setiap hari menjelang mulai membangun balai.

Sebelum pembangunan balai dimulai, depati kembali mengumpulkan warga dalam satu musyawarah untuk membentuk panitia bimbang. Musyawarah bertujuan untuk menunjuk orang-orang yang akan mengisi jabatan kepanitiaan. Seluruh pekerjaan tersebut dikerjakan sesuai prinsip tradisi ngeresayo. ${ }^{4}$ Umumnya jumlah panitia sebanyak 40 orang yang

\footnotetext{
${ }^{3}$ Mengundang muda mudi dari dusun lain merupakan tradisi pergaulan muda mudi Serawai. Peran muda mudi sangat penting karena mereka membantu keperluan selama acara bimbang, seperti memasak yang dikerjakan beramai-ramai. Kesempatan ini dimanfaatkan oleh muda mudi untuk saling mengenal dan sekaligus ajang mencari jodoh. Sehari sebelum acara bimbang, biasanya diadakan acara gegeritan yaitu malam hiburan bagi muda mudi dan pengantin. Para muda mudi akan menari berpasang-pasangan namun tidak boleh berasal dari dusun yang sama (Dihamri 2017:68-69).

4 Tradisi ngerasayo adalah tradisi gotong royong pada suku bangsa Serawai untuk mengerjakan suatu pekerjaan. Seluruh pekerja tidak dibayar, tuan rumah hanya menyediakan makan dan minum selama pekerjaan dilakukan.
} 
Handep Jurnal Sejarah dan Budaya Vol. 4, No. 1, Desember 2020, hlm. 87-110

terbagi dalam beberapa jabatan, berikut ini.

1. Imam bimbang (satu orang), sebagai ketua panitia yang bertanggung jawab terhadap pelaksanaan bimbang.

2. Porwatin tujuh, terdiri dari tujuh orang depati.

3. Inang delapan, adalah orang yang akan memangil penari-penari untuk menari secara berpasangan. Pasangan penari harus berbeda asal dusunnya. Inang juga akan menarikan tari-tarian adat dalam acara bimbang, atau orang yang membuka tarian tersebut.

4. Tukang sirih adalah anak bujang gadis yang menyirih atau mengundang masyarakat di desa tetangga dengan membawa sirih selengkapnya. Tukang sirih dibutuhkan sebanyak mungkin sehingga seluruh panitia akan berjumlah sekitar empat puluh orang.

5. Tuo bimbang pengantin laki-laki adalah orang yang bertugas untuk menjaga pengantin laki-laki dan mencukupi kebutuhan pengantin laki-laki apapun bentuknya saat acara bimbang sedang dilaksanakan.

6. Tuo bimbang perempuan adalah orang yang bertugas untuk menjaga pengantin perempuan dan mencukupi kebutuhan pengantin perempuan apapun bentuknya saat acara bimbang sedang dilaksanakan.

7. Apit laki-laki dan perempuan adalah kaum pengantin pihak laki-laki dan pihak perempuan.
8. Tukang masak adalah orang yang akan memasak makanan selama acara bimbang.

9. Tukang lampu adalah orang yang bertugas mempersiapkan penerangan jegangkang (sejenis obor terbuat dari bambu besar yang dipakai pada saat acara bimbang pada malam hari).

Pelaksanaan tradisi bimbang bebalai dilaksanakan selama tiga hari. Hari pertama dimulai dengan prosesi akad nikah menurut agama Islam di masjid atau di rumah calon pengantin perempuan. Setelah akad nikah selesai, kedua pengantin yang berpakaian adat diarak dari rumah menuju balai yang sudah dibangun, diiringi orang tua dan kerabatnya, imam balai, pasirah, depati, dan rombongan lainnya.

Sesampai di balai, rombongan melakukan tradisi munga balai yaitu mengelilingi balai sebanyak tujuh kali. Tujuannya adalah untuk menjaga keamanan pelaksanaan acara agar tidak diganggu oleh orang-orang yang berniat jahat kepada kedua pengantin. Munga balai juga bertujuan untuk memberikan kesempatan kepada seluruh tamu yang hadir untuk memberikan restu dan doa kepada pengantin tersebut. Setelah arak-arakan selesai, pengantin dipersilakan menempati tempat duduk yang telah disediakan. Arak-arakan diakhiri dengan pelaksanaan tari Bunting Penganten yang dilakukan oleh kedua pengantin diikuti oleh masyarakat yang ingin ikut menari. 
Acara selanjutnya adalah nyuriak yakni acara berpantun yang dilakukan dengan saling bersahutan. Acara ini dikhususkan untuk muda mudi (bujang gadis) dusun setempat dengan muda mudi (bujang gadis) dari dusun tetangga. Pantun diawali dari bujang gadis dusun setempat. Isi pantun biasanya tentang perasaan kepada muda mudi dari dusun tetangga yang hadir di acara terebut. Pantun tersebut akan dibalas oleh muda mudi dusun tetangga yang merasa isi pantun tersebut ditujukan kepada dirinya atau perwakilan dari muda mudi sebagai respon terhadap isi pantun yang disampaikan oleh muda mudi dusun setempat.

Pantun yang disampaikan oleh seorang pemuda harus dibalas oleh pemudi dari dusun yang berbeda. Hal ini terkait dengan adanya larangan pada masyarakar Serawai menikah satu dusun. Tidak jarang tradisi nyuriak dijadikan sebagai sarana mencari jodoh atau menyampaikan rasa cinta seorang, yang pada akhirnya berlanjut hingga ke jenjang pernikahan. Acara ini akan selesai ketika tidak ada lagi di antara mereka yang merespon atau setelah ada kesepakatan untuk menyudahi kegiatan tersebut karena harus melaksanakan tahapan acara berikutnya. Pada acara ini peran inang delapan sangat dibutuhkan untuk mengatur siapa muda mudi yang akan berpantun untuk menghindari terjadinya berbalas pantun antara muda mudi yang berasal dari dusun yang sama. Nyuriak diakhiri dengan acara makan bersama seluruh orang yang hadir.

Pada malam hari setelah salat Isya dilanjutkan dengan penampilan kesenian berupa sastra lisan seperti rejung, ${ }^{5}$ berpantun, tari Andun, gegerit, berdendang, tari Mumbang Melayu, tari Pencak Silat, tari Lagu Duo, tari Selendang, dan tari Piring.

Acara di hari kedua hingga hari terakhir relatif sama yaitu hiburan bagi masyarakat. Pada hari terakhir, sebagai penutup seluruh rangkaian acara, dilaksanakan penyembelihan hewan yang jenisnya tergantung pada keluarga pengantin. Hewan yang umumnya disembelih adalah kerbau karena dianggap simbol kemakmuran dan tingkat status sosial keluarga tersebut.

Pada saat hewan akan disembelih, kedua pengantin menari Numbak Kebau. Tarian ini dilakukan dengan menggunakan sebuah lidi daun kelapa. Lidi sepanjang sekitar $50 \mathrm{~cm}$ dipisahkan dari daun kelapa. Setelah itu lidi dibersihkan dan diruncingkan ujungnya. Tradisi ini dilaksanakan pada subuh hari sebelum matahari terbit. ${ }^{6}$ Kerbau ditambatkan pada sebuah pohon atau tiang yang kokoh di sebuah lapangan di sekitar lokasi bimbang. Kedua pengantin dengan pakaian adat

\footnotetext{
5 Rejung adalah pantun saling bersahutan dengan irama tertentu antara laki-laki dengan perempuan yang belum menikah (saat ini sudah bebas dilantunkan oleh yang sudah menikah). Penjelasan lebih lanjut bisa dibaca pada Sarwono (2017).

${ }^{6}$ Namun pada masa sekarang sudah dilakukan lebih siang sekitar pukul 08.00.
} 
Handep Jurnal Sejarah dan Budaya Vol. 4, No. 1, Desember 2020, hlm. 87-110

berdiri dengan jarak 2-3 meter dari tempat kerbau. Pengantin laki-laki dan perempuan memegang sebuah kelapa hijau dengan tujuh buah lidi yang ditancapkan di kelapa tersebut. Pengantin mengelilingi kerbau sebanyak tujuh kali ke kanan dan tujuh kali ke kiri sambil memegang buah kelapa. Selesai mengelilingi kerbau, lidi tersebut dilemparkan ke arah kepala kerbau. Pengantin laki-laki melemparkan lidi ke kepala kerbau terlebih dahulu sebanyak tiga kali dan dilanjutkan oleh pengantin perempuan sebanyak tiga kali. Lemparan lidi yang tepat berada di kepala kerbau memberi makna bahwa akan ada hal baik setelah pernikahan kedua mempelai. Sebaliknya jika lemparannya meleset atau melayang, maka akan ada hal buruk yang akan terjadi.

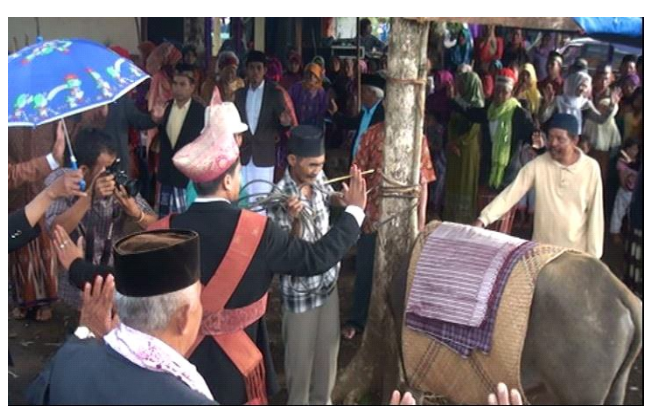

Gambar 2. Tari Numbak Kebau di pihak lakilaki. Sumber: Viadinata 2016:81.

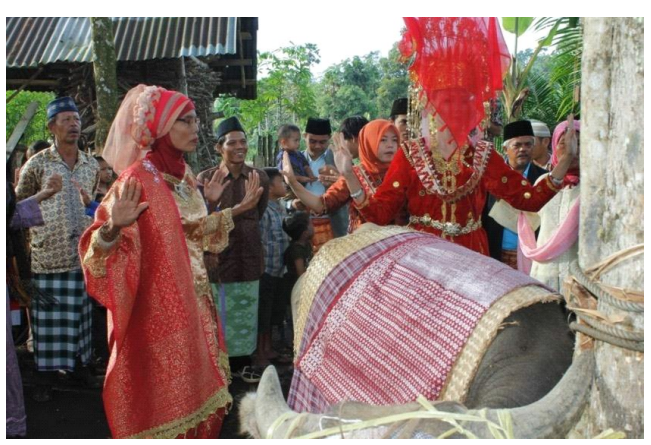

Gambar 3. Tari Numbak Kerbau di pihak pengantin perempuan. Sumber: Viadinata 2016:81.
Setelah prosesi Numbak Kebau selesai dilaksanakan, imam balai akan memimpin acara penyembelihan kerbau. Kerbau yang disembelih tersebut selanjutnya dimasak sebagai hidangan makan siang (batan gulai) dan sebagian dibagikan kepada seluruh panitia yang terlibat sebagai ucapan terima kasih atas kesediaan mereka menyukseskan acara bimbang bebalai.

Bagian-bagian tertentu dari kerbau sembelihan digunakan untuk pelaksanaan tradisi kayak belansi yaitu tradisi pemberian daging kerbau yang dilemparkan ke Sungai Nago Rayo sebagai persembahan untuk binatang yang ada di sungai. Hal ini berangkat dari cerita rakyat Serawai tentang seekor naga yang besar. Tradisi kayak belansi dilakukan pada sore hari menjelang Maghrib. Tata cara pelaksanaan tradisi ini adalah (a) semua jenis daging kerbau yang disembelih diambil segenggam, baik itu daging, hati, dan tulang-tulangnya, (b) daging yang tidak boleh dicuci (dibiarkan masih berbau darah) dibungkus dengan kain putih polos lalu diikat dengan tali, (c) daging dilempar ke dalam sungai yang berarus deras. Pada malam harinya jika terjadi hujan deras dan petir kilat menyambar, maka masyarakat percaya bahwa tradisi kayak belansi diterima oleh roh leluhur dan dengan demikian tradisi bimbang bebalai diterima oleh Yang Maha Kuasa. Jika hujan dan petir kilat tidak ada pada malam harinya, maka tradisi seserahan ini tidak diterima. 
Sebelum acara ditutup, imam balai dan beberapa anggota panitia lainnya, termasuk perwakilan keluarga pengantin, menyampaikan telibon yaitu pidato adat berupa ucapan terima kasih kepada semua pihak yang terlibat selama acara bimbang bebalai. Seluruh rangkaian kegiatan ditutup dengan doa yang dipimpin oleh imam masjid atau orang yang dituakan di dusun tersebut. Acara dilanjutkan dengan makan bersama seluruh pihak yang terlibat, seluruh warga dusun, dan juga alang judu (muda mudi yang belum mendapat pasangan atau jodoh) dengan harapan akan segera mendapatkan jodoh mereka.

\section{Kesenian pada Tradisi Bimbang Bebalai}

\section{a. Tari}

Tradisi bimbang bebalai di samping sebagai sarana pemberian doa kepada pasangan pengantin, juga sebagai sarana hiburan bagi masyarakat setempat, dusun/desa tetangga yang diundang, maupun orang-orang yang datang untuk mencari hiburan.

Kesenian Serawai yang ditampilkan sebagai sarana hiburan adalah tari, rejung, dan pantun. Pada suku bangsa Serawai, tari Andun merupakan tari utama yang wajib ditampilkan dalam setiap bimbang karena dianggap sakral sesuai dengan kepercayaan mereka terhadap sejarah tari itu sendiri. Tari Andun adalah nama umum untuk berbagai tari dengan fungsi dan aturan pelaksanaan yang berbeda. Namun taritari tersebut menggunakan musik pengiring yang sama, yaitu kolintang dan rebana, sehingga irama yang dihasilkan mirip.

Tari Andun dianggap sakral dan menjadi tari utama karena terkait dengan sejarah suku bangsa Serawai. Dalam cerita rakyat yang dikenal masyarakat Serawai dikisahkan seperti berikut.

Tari Andun ini pertama kali ditampilkan saat pesta perkawinan antara Putri Bungsu Sungai Ngiang Pagar Ruyung dengan Dangku Rajau Mudau di Kerajaan Dang Tuanku Limau Serumpun daerah Bengkulu Selatan pada zaman dahulu. Perayaan pesta perkawinan dengan menggunakan tarian merupakan wujud tanda syukur Dayang Remunai ibunda Rajau Mudau atas keselamatan Putri Bungsu yang sebelumnya diculik oleh Imam Jaya dari Kerajaan Sangkalawi. Atas perintah Dayang Remunai, Cindur Matau kakak dari Rajau Mudau diperintahkan untuk menyelamatkan Putri Bungsu dengan membawa si Benuang (seekor kerbau jantan) sebagai hadiah untuk Kerajaan Sangkalawi agar tidak ada kecurigaan dengan penyamarannya dan $\mathrm{Si}$ Gumarang (seekor kuda) sebagai tunggangan Cindur Matau. Setelah Putri Bungsu berhasil diselamatkan dan dibawa kembali oleh Cindur Matau ke Kerajaan Dang Tuanku Limau Serumpun, pernikahan antara Putri Bungsu dengan Rajau Mudau segera dilaksanakan selama tujuh hari tujuh malam (Viadinata 2016:34).

Berdasarkan hasil wawancara dengan Jamahari tanggal 21 Juli 2019 di Sukaraja, tari Andun yang ditampilkan selama pelaksanaan 
Handep Jurnal Sejarah dan Budaya Vol. 4, No. 1, Desember 2020, hlm. 87-110

bimbang bebalai terdiri atas beberapa tari-tarian dengan fungsi dan urutan yang berbeda seperti berikut.

1) Tari Kebanyakan (tari pembukaan). Tari ini sebagai tari pembuka saat acara adat dimulai. Pada acara bimbang bebalai, tarian ini disajikan sebagai tari pembukaan yang dilaksanakan pada malam gegerit. Para penarinya adalah setiap orang yang hadir dan berminat menari tanpa dibatasi sebagai bentuk penyambutan dan penghormatan tuan rumah kepada para tamu yang hadir. Para penari dibagi dalam kelompok laki-laki dan perempuan dan tidak boleh bercampur, sehingga tempatnya diatur agar berjarak supaya para penarinya tidak terganggu. Setiap kelompok menari dengan berputar sebanyak tujuh kali mengikuti arah jarum jam dengan diiringi musik tradisional.

2) Tari Lelawanan. Tari ini secara umum sama dengan tari Kebanyakan namun memiliki fungsi dan aturannya sendiri. Tarian ini dikhususkan bagi muda mudi dewasa dan tidak ada hubungan darah. Hal ini disebabkan tarian ini dikhususkan sebagai ajang mencari jodoh dan adat Serawai melarang adanya perkawinan sedarah dan sedusun. Para penari diatur oleh dua orang inang laki-laki dan dua orang inang perempuan. Inang inilah yang mengatur pasangan yang boleh menari dengan memperhatikan hubungan darah dan tempat tinggal si penari agar tidak terjadi incest taboo. Pelaksanaan tari ini pertama kali dilaksanakan pada malam hari sebagai pembuka acara bimbang bebalai. Acara menari ini akan selesai jika sudah tidak ada lagi penari yang berpasangan sesuai aturan adat. Tari ini juga dilaksanakan pada hari berikutnya di siang hari yaitu setelah tari Numbak Kebau sambil menunggu batan gulai. Tari ini akan selesai jika tuau kerjau (ketua panitia) mengumumkan bahwa hidangan sudah tersedia dan seluruh tamu yang hadir dipersilakan menikmati hidangan yang telah tersedia.

4) Tari Numbak Kebau.

5) Tari Palak Tanggau. Sebelum pengantin perempuan (bunting) memasuki rumah pengantin pria atau rumah mertuanya, ia harus menari di depan rumah tersebut sebagai bentuk penghormatan kepada keluarga mertuanya. Pengantin menari Palak Tanggau didampingi oleh tuo bimbang bunting (pendamping bunting) dan keluarga pihak perempuan. Pada saat bunting menari, ibu pengantin laki-laki akan mengalungkan (mengikat) selendang ke bunting sebagai tanda keluarga pihak perempuan sudah diterima. (Viadinata 2016:82).

6) Tari Lelawan Perpisahan. Tari ini sama dengan tari Lelawanan sebelumnya namun merupakan tarian yang khusus bagi kedua 
pengantin, karena sebagai tari perpisahan dengan muda mudi sedusun dan teman-teman lainnya. Pengantin pria maupun wanita boleh menari dengan pria atau wanita lain setelah mendapatkan izin dari pasangannya. Tari ini dilaksanakan pada malam terakhir rangkaian acara bimbang bebalai yaitu malam gegerit, sekaligus sebagai penutup dari seluruh kegiatan bimbang bebalai.

\section{b. Pantun dan Ungkapan}

Pantun dan ungkapan pada suku bangsa Serawai merupakan keahlian yang harus dimiliki termasuk para muda mudinya. Setiap rangkaian bimbang selalu diisi dengan acara berbalas pantun sebagai sarana untuk menyampaikan maksud kepada seseorang. Demikian juga pada acara bimbang bebalai yang menjadi sarana pertemuan muda mudi dari berbagai dusun, berbalas pantun dihadirkan sebagai salah satu bagian dari rangkaian acaranya.

Jamahari di Sukaraja, pada 21 Juli 2019 menjelaskan bahwa beberapa tema pantun pada masyarakat Serawai dapat dikelompokkan dalam beberapa bagian seperti berikut.

1) Ungkapan yang populer pada masyarakat Serawai pada masa dahulu sebelum memasuki jenjang pernikahan yang mengungkapkan agar pasangan tetap setia:

Kalung pirak kalung pirunggu Ndak buleh dibawa makan bakso ${ }^{7}$ Satu syarak keduo dimadu Kalau pacakjangan dicubo

Terjemahan:

Kalung perak kalung perunggu Tidak boleh dibawa makan bakso Satu cerai kedua dimadu Kalau bisa jangan dicoba

Artinya:

Maksudnya pertama cerai, kedua dimadu, kalaupun bisa jangan dicoba. Cukup satu istri saja.

2) Ungkapan waktu mengundang orang dari kampung lain untuk ikut menghadiri acara bimbang bebalai. Ungkapan ini disampaikan oleh muda mudi perwakilan dusun/ kampung yang akan mengadakan bimbang bebalai kepada muda mudi kampung lain yang akan diundang.

Ini lengguai dan sirih pinang Adat limbago kito Serawai Sirih pinang minta disubang Pertando kami bejalan lah sampai

Terjemahan: Ini lengguai (carano) dan sirih pinang Adat lembaga kita Serawai Sirih pinang minta diambil Pertanda kami berjalan sudah sampai Jawaban:

Sirih pinang lah kami subang Tando kalian bejalan lah sampai

7 Bakso disini adalah istilah yang dipakai sebagai contoh oleh informan untuk menyebutkan makanan yang disukai muda mudi. 
Handep Jurnal Sejarah dan Budaya Vol. 4, No. 1, Desember 2020, hlm. 87-110

3) Ungkapan muda mudi waktu acara nyuriak (salah satu rangkaian dari kegiatan bimbang bebalai) di balai setelah makan siang.

Dari pihak laki-laki:

Bulan terang menembak babi

Tembak pado anak risau

Sebulan antak tak mandi

Nunggu sianu nunjuak limau

Balasan dari pihak perempuan:

Limau manis masak sepiak

Sesiung dibunggung burung

Itam manis menutul tinjak

Tinjak berencung pucuk burung

Dibalas lagi oleh pihak laki-laki

Gununang bungkuak ulu Bengkulu

Nendaki dagang pulau tikus

Merunduak ati merindu

Banyu mato gendun putus

Jawab perempuan

Putus tali gendang serunai

Lubuak belimbangan buayo

Putus hati rindu ngepunai

Punai di puncak hati rindu

Serengkayo jangan dikubak

Kalau dikubak masak galo

Serilo jangan dibuka

Kalau dibuka ngungkar galo

Abih kedabuak bepuluah buak

Abih kemanyan bepuluah gan

Abih ngmbiak luakan cibuak

Nyo dimuko lagi banyak

Nyo di belakang lagi atiak

Melanciak batang salak

Batang serian di jerami

Mintak setabiak niniak mamak

Kami nak cangkiang mangkuak

kendi
4) Rejung disampaikan sebagi ungkapan isi hati seorang bujang (pemuda) kepada gadis (pemudi) lain dan sebaliknya. Perbedaan dengan pantun secara umum adalah rejung disampaikan dengan irama tertentu dengan tempo yang lambat, sedangkan pantun disampaikan lebih spontan dan lugas. Beberapa contoh ungkapan dalam rejung:

Kemana andun menyabung Ke Musi mengilir taji

Singga bepulang di pengkinang

Muncul kayam di belitiak

Dalam rejung sudut kuantak

Dalam rejung sudut kendung dalam nyanyi

Kalau bungo suko dikarang

Kapas ndak jadi benang putiak

Dari kapas hendak dijadikan

benang

Dari kawan hendak dijadikan istri

Dinganu rantau panjang

Jangan dimandi rantau panjang sudo ditubo di ulu

Tanamkan pudding berangini

Narik sampai berang sano

Dinganu luluak sayang pecah bae luluak sayang

Timbang mobae seding suko Apung sayang apoloh ini Apung dimambang diak beguno

Tiada gading yang tak retak

Tiada kata yang tak salah

Retak gading karena disalah

Salah dikata karena manusia biasa 
5) Ungkapan yang digunakan oleh calon pengantin laki-laki kepada calon mertuanya ketika akan memulai melamar anak gadis.

Selepah selepuk selempuri

Sembah bujur sembah melintang

Sembah sepuluh jari didepan

Mohon dengan bapak nikahkan

anak bapak dengan aku

6) Ungkapan yang digunakan untuk menentukan hari baik dalam menentukan waktu yang tepat untuk melaksanakan tradisi bimbang bebalai yang biasanya ditentukan oleh imam bimbang:

Hari iluak bulan betuah

Hari rang hari gumarang

Hari beruak memarang lebang

Beruak besak ngugak ciuang mampang ndak an

Pada zaman dahulu, terutama pada masa sistem pemerintahan marga yang dipimpin oleh pasirah, untuk melaksanakan sebuah bimbang terlebih dahulu harus bertanya kepada ketua adat atau yang dianggap memiliki kemampuan memilih hari baik. Orang yang memiliki kemampuan inilah yang ditunjuk sebagai imam bimbang. Hari baik yang diharapkan itu ditandai dengan waktu acara tidak akan hujan, orang yang datang ramai dan sebagainya.

7) Pantun muda mudi lainnya di suku Serawai.

Alang kelemak mandi di hulu Bemandi bawa kariet Alang kelemak menjadi guru Aku menjadi anak murid

Terkukum madang di jalan Hanyut terndam batang pauh Hati rindu liatin bulan

Kito berdendang samo jauh

Teratak buluah teriti batang teberau berang sano

Teragak lum teriti segut kintang batak kato

\section{Pelestarian Tradisi Bimbang Bebalai}

Jamahari di Sukaraha, pada 20 Juli 2019 menjelaskan bahwa tradisi bimbang bebalai mulai dikenal sejak diberlakukannya Undang-Undang Simbur Cahaya oleh kolonial Belanda pada akhir abad ke-19 dan awal abad ke-20. Dalam undang-undang tersebut disebutkan bahwa pada wilayah Onderafdeling Seloema terdapat tiga cara bimbang yaitu (1) cara Melayu yang ditandai dengan main biola gendang, serunai, dan tari-tarian. (2) cara Ulu yang ditandai dengan main gung, kelintang, dan menari bujang gadis. (3) cara Malin yang ditandai dengan berzikir dan membaca ayat suci Al-Quran.

Saat ini jenis bimbang yang dilaksanakan oleh masyarakat di Kabupaten Seluma adalah sebagai berikut.

1) Bimbang sepagi, yaitu upacara perkawinan yang diselesaikan dalam waktu satu hari dan dilaksanakan secara sederhana, mengacu pada agama Islam, dan tidak diharuskan memotong kerbau atau sapi melainkan kambing. 
2) Bimbang caro ulu, yaitu upacara perkawinan yang menggunakan adat Serawai, dilaksanakan selama satu hari atau jika mampu bisa dilakukan selama tiga hari, dan dilaksanakan di rumah pengantin laki-laki. Jenis bimbang ini menampilkan tari-tarian seperti tari Ulu, tari Khalipa, tari Anam, dendang Melayu. Jamuan bisa dengan memotong kerbau atau sapi.

3) Bimbang bebalai, yaitu upacara perkawinan yang diselenggarakan di balai di satu tempat khusus.

Jenis upacara perkawinan ini mulai dilembagakan sejak diterbitkannya Peraturan Daerah Kabupaten Seluma No. 4 tahun 2014 tentang Kompilasi Hukum Adat di Kabupaten Seluma. Salah satu poin dalam peraturan daerah mengatur pelaksanaan tradisi bimbang bebalai yang telah direkonstruksi sesuai dengan pemahaman mereka saat ini. Meskipun sudah diatur di peraturan daerah, tradisi ini belum pernah dilaksanakan oleh masyarakat atau dengan fasilitasi pemerintah.

"Untuk daerah Sukaraja, terakhir bimbang bebalai dilaksanaan pada tahun 1952" ujar Jamahari di Sukaraja pada 20 Juli 2019. Sedangkan menurut Zairin Rasul, Ketua BMA Kabupaten Seluma di Bengkulu pada 21 Juli 2019, bimbang bebalai di wilayah Semidang Alas terakhir kali dilaksanakan pada 1967.

Menurut mereka, penyebab tidak dilaksanakannya tradisi bimbang bebalai adalah sebagai berikut.
1. Semakin sulitnya mengumpulkan warga yang bisa bekerja selama 3-5 hari akibat kesibukan dan semakin kompleksnya sumber mata pencaharian.

2. Dana yang dibutuhkan cukup besar sehingga tidak ada warga yang mau untuk melaksanakannya.

3. Rumitnya tata urutan pelaksanaan bimbang bebalai karena melibatkan cukup banyak unsur.

4. Kurangnya pengetahuan masyarakat tentang konsep dan substansi tradisi bimbang bebalai tersebut.

5. Sulitnya mencari bahan-bahan yang akan digunakan untuk membangun balai.

Upacara bimbang bebalai oleh masyarakat adat Serawai di Kabupaten Seluma dianggap sebagai tradisi khas Kabupaten Seluma. Mereka mendesak Pemerintah Kabupaten Seluma untuk segera melakukan upaya pelestarian. Pemerintah Kabupaten Seluma merespon permintaan ini dengan menerbitkan Peraturan Daerah No. 4 tahun 2014 yang salah satu babnya menegaskan perlunya pelaksanaan upacara bimbang bebalai.

Pemerintah Kabupaten Seluma berencana melaksanakan acara bimbang bebalai sebagai upaya menindaklanjuti peraturan daerah dan sekaligus bentuk dukungan pariwisata. Kegiatan ini dilaksanakan oleh Dinas Pariwisata Kabupaten Seluma yang direncanakan akan diselenggarakan pada 8-10 Agustus 2019 di Balai Adat di Tais. Menurut Rijono, Kepala Bidang Destinasi di Dinas Pariwisata 
Kabupaten Seluma di Tais pada 22 Juli 2019 "persiapan kegiatan ini dilakukan dengan mengumpulkan informasi tentang tradisi bimbang bebalai. Beberapa tokoh didatangi untuk wawancara terkait deskripsi tradisi yaitu Bapak Jamahari dan Bustan A. Dali." Irwan di Tais pada 22 Juli 2019 juga menjelaskan "kegiatan bimbang bebalai berkoordinasi dengan Dinas Pendidikan dan Kebudayaan Kabupaten Seluma terutama dalam pengumpulan data dan atribut lain yang dibutuhkan."

"Sulitnya merekonstruksi tradisi bimbang bebalai karena memang sudah cukup lama tidak pernah dilaksanakan dan sebagian besar yang pernah mengalaminya sudah meninggal. Informasi yang bisa didapat hanya melalui Bapak Bustan A. Dali dan Bapak Jamahari," ujar Yanda, Kepala Bidang Kebudayaan Dinas Pendidikan dan Kebudayaan Kabupaten Seluma di Semidang Alas pada 19 Juli 2019. Persiapan yang dilakukan oleh Dinas Pariwisata Kabupaten Seluma dalam upaya merekonstruksi tradisi bimbang bebalai mengacu pada proposal usulan yang dibuat oleh Bustan A. Dali.

"Rencana pergelaran tradisi bimbang bebalai ini gagal dilaksanakan dengan alasan kurangnya anggaran," ujar Irwan dan Rijono pada 7 Agustus 2019. Informasi pembatalan kegiatan ini mendapat berbagai respon dari kalangan masyarakat di Kabupaten Seluma terutama dengan alasan kurangnya anggaran (Pedoman Bengkulu 2019).

Gagalnya pelaksanaan tradisi bimbang bebalai secara teoritis bisa dipahami karena tidak berfungsinya struktur yang ada pada tradisi tersebut. Ada kecenderungan pemerintah daerah tidak memahami peran dan fungsi yang melekat pada setiap struktur pelaksanaan tradisi bimbang bebalai. Hal ini terlihat dari ketergantungan mereka pada informasi yang diberikan oleh Jamahari dan Bustan A. Dali.

Peran pasirah sebagai unsur pemerintah dan adat pada masa lalu tidak berhasil dijalankan oleh kepala dinas sebagai ketua panitia, misalnya dengan ketidakberhasilan mengisi struktur yang seharusnya ada seperti imam bimbang, inang delapan, dan lain-lain. Jika dilihat dari peran bidang kebudayaan, Ketua Badan Musyawarah Adat Kabupaten Seluma idealnya menjadi ketua panitia untuk menjalankan peran pasirah sebagai pemimpin bidang adat.

Keberadaan porwatin pada masa lalu secara struktur bisa diperankan oleh kepala desa pada masa sekarang namun hal ini tidak ditemui lagi dalam aktivitas adat suku bangsa Seluma. Pada aktivitas adat perkawinan, beberapa peran yang masih ditemui saat ini adalah peran apit dan tuo bimbang. Adapun peran yang sudah tidak ada lagi dan tidak bisa digantikan adalah peran tukang sirih dan peran inang delapan.

Sesuai dengan analisis fungsional struktural Radcliffe-Brown, dengan tidak terisinya struktur tersebut 
Handep Jurnal Sejarah dan Budaya Vol. 4, No. 1, Desember 2020, hlm. 87-110

maka fungsi dari setiap peran dalam tradisi bimbang bebalai tidak bisa dilaksanakan.

Idealnya ide ataupun semangat pelaksanaan sebuah tradisi berasal dari masyarakat adat sebagai struktur pelaksana tradisi. Pemerintah hanya sebagai fasilitator, bukan bagian dari struktur pelaksana tradisi bimbang bebalai.

Berikut ini adalah beberapa hal yang menjadi penyebab gagalnya pelaksanaan tradisi bimbang bebalai terkait dengan kurangnya pelibatan lembaga adat dan masyarakat.

1) Tidak dilibatkannya Lembaga adat yaitu Badan Musyawarah Adat (BMA) Kabupaten Seluma. Menurut Zairin Rasul, Ketua BMA Kabupaten Seluma di Bengkulu pada 21 Juli 2019, BMA tidak dilibatkan dalam rencana pelaksanaan tradisi bimbang bebalai, padahal data untuk merekonstruksi tradisi tersebut bisa dikumpulkan melalui BMA.

2. Dukungan Pemerintah Kabupaten Seluma sudah cukup baik dengan menerbitkan peraturan daerah tentang kompilasi hukum adat, namun peraturan daerah tersebut tidak tersosialisasikan ke masyarakat sebagai pelaksana tradisi tersebut. Hal ini juga terlihat dari minimnya respon masyarakat terhadap rencana tersebut.

3. Kepanitiaan yang dibentuk oleh pemerintah daerah tidak mengacu pada kepanitiaan yang dibentuk secara adat pada masa bimbang bebalai masih dilaksanakan. Panitia yang dibentuk pemerintah adalah para pegawai pemerintah daerah yang pada dasarnya tidak terlibat langsung dalam adat. Dengan demikian peran yang seharusnya ada tidak ditemukan pada kepanitiaan ini.

\section{SIMPULAN}

Tradisi bimbang bebalai merupakan penggabungan dari tiga jenis bimbang dalam adat pernikahan suku bangsa Serawai di Kabupaten Seluma. Dalam persebarannya tradisi ini terdapat di wilayah kebudayaan Serawai yang meliputi Kabupaten Seluma, Kabupaten Bengkulu Selatan, dan sebagian wilayah Kabupaten Kaur.

Berdasarkan analisis fungsional struktural, tradisi ini melibatkan struktur yang rumit dengan berbagai peran yang harus dijalankan oleh setiap orang. Pada masa pemerintahan marga, pasirah sangat berperan dalam mengatur aktivitas masyarakat termasuk dalam adat. Seiring hilangnya sistem pemerintahan tradisional, urusan budaya menjadi tanggung jawab pemerintah daerah melalui dinas terkait.

Tradisi bimbang bebalai pada masa pemerintahan marga dapat dilaksanakan karena setiap peran pada tradisi tersebut berfungsi. Berbeda halnya dengan saat ini, pelaksanaan tradisi bimbang bebalai disiapkan tanpa melibatkan seluruh pihak yang berperan dalam tradisi tersebut. 
Struktur yang dibentuk oleh pemerintah ternyata tidak didukung dengan pemahaman terhadap peran-peran yang ada pada struktur itu, yang dengan sendirinya menyebabkan tradisi tersebut tidak bisa dilaksanakan.

\section{E. REKOMENDASI}

Terkait dengan pelestarian sebuah tradisi suatu suku bangsa hendaknya diperhatikan beberapa rekomedasi sebagai berikut:

a. mendokumentasikan secara lengkap seluruh aktivitas tradisi baik dalam bentuk tulisan dan audio visual;

b. memberikan peran yang lebih besar kepada masyarakat adat dalam pelaksanaan sebuah tradisi daripada peran pemerintah;

c. hendaknya pemerintah hanya sebatas fasilitator daripada sebagai eksekutor dalam pelaksanaan tradisi;

d. memfasilitasi lembaga adat di tingkat desa atau kecamatan dalam kegiatan sosialisasi sebuah tradisi agar dipahami oleh seluruh lapisan masyarakat.

\section{DAFTAR SUMBER}

Afrizal. 2014. Metode Penelitian Kualitatif: Sebuah Upaya Mendukung Penggunaan Penelitian Kualitatif dalam Berbagai Disiplin Ilmu. Jakarta: Raja Grafindo Persada.

Arief, Eza Adhitya. 2018. "Perancangan Informasi Tari Andun Melalui Media Video Profil." Universitas
Komputer Indonesia Bandung, Bandung.

Arios, Rois Leonard. 2004. Kebudayaan Suku Bangsa Enggano di Bengkulu. Padang: Balai Kajian Sejarah dan Nilai Tradisional.

2019. "Pertukaran Sosial dalam Tradisi Pantawan Bunting pada Suku Bangsa Besemah di Kota Pagaralam Provinsi Sumatra Selatan." Patanjala: Jurnal Penelitian Sejarah dan Budaya 11(3):467-82. . 2007. Kutei: Konsep dan Permasalahannya pada Suku Bangsa Rejang. Jakarta: Kementerian Kebudayaan dan Pariwisata.

Bungin, Burhan. 2011. Penelitian Kualitatif: Komunikasi, Ekonomi, Kebijakan Publik, dan Ilmu Sosial Lainnya. Jakarta: Kencana.

Corbin, Juliet and Anselm Strauss. 2008. Basics of Qualitative Research: Techniques and Procedures for Developing Grounded Theory. California: Sage Publications Inc.

Dali, Bustan A. 2004. Daerah Seluma dalam Sejarah Asal Usul Pertumbuhan dan Perkembangan. Tais: Yayasan Pembangunan Kabupaten Seluma.

Depdikbud. 1978. Kebudayaan Bengkulu. Jakarta: Proyek 
Penelitian dan Pencatatan

Kebudayaan Daerah.

Dihamri. 2017. "Budaya Daur Hidup (Siklus Kehidupan) Suku Serawai di Kabupaten Bengkulu Selatan." Jurnal Georafflesia: Artikel Ilmiah Pendidikan Geografi 2(2):61-75.

Fitriani, Dwi Septi. 2019. "Makna Tari Napa pada Bimbang Adat Suku Serawai di Kota Manna Kabupaten Bengkulu Selatan." Jurnal Sosiologi Nusantara 5(1):121.

Haviland, William A. 1999. Cultural Anthropology $9^{\text {th }}$ Edition. Florida: Harcourt Brace College Publishers.

Hoesin, Kiagoes. 1938. Koempoelan Oendang-Oendang Adat Lembaga dari Sembilan Onderafdelingen dalam Gewest Benkoelen. Bengkoelen: Drukkerij “Tjan.”

Koentjaraningrat. 1987. Sejarah Teori Antropologi 1. Jakarta: UI Press.

Koentjaraningrat. 2013. Pengantar Ilmu Antropologi. Jakarta: Rineka Cipta.

Marzali, Amri. 2014. "StrukturalFungsionalisme."Jurnal Antropologi 52(1).

Octaviani. 2017. "Pola Komunikasi Adat Berasan Suku Serawai di Era Modern." Jurnal ASPIKOM 3(2):1730-85.

Pedoman Bengkulu. 2019. "Festival Bimbang Bebalai Seluma Gagal
Digelar." Pedoman Bengkulu. Diunduh 8 Agustus 2019 (http:// pedomanbengkulu.com/2019/08/ festival-bimbang-bebalai-selumagagal-digelar/).

Pemerintah Kabupaten Seluma. 2014. "Peraturan Daerah Kabupaten Seluma No 4 Tahun 2014 tentang Pemberlakukan Kompilasi Hukum Adat di Kabupaten Seluma."

Radcliffe-Brown, A.R. 1952. Structure and Function in Primitive Society. Illinois: The Free Press.

Refisrul. 2019. "Fungsi Lemang dalam Upacara Perkawinan Suku Besemah di Kabupaten Kaur Provinsi Bengkulu." Jurnal Penelitian Sejarah dan Budaya 5(2):235-56.

Sarwono, Sarwit et al. 2005 Sejarah dan Adat Istiadat Kabupaten Mukomuko. Mukomuko. Mukomuko: Bappeda Kabupaten Mukomuko.

Sarwono, Sarwit, Agus Joko Purwadi. 2017. "Folklore Rejung pada Kelompok Etnik Serawai di Provinsi Bengkulu." Masyarakat, Kebudayaan dan Politik 26(3):182-92.

Spradley, P. J. 1997. Metode Etnografi. Yogyakarta: Tiara Wancana.

Viadinata, Losa. 2016. "Makna Simbolik Tari Andun dalam Upacara Adat Perkawinan pada Masyarakat Kecamatan Kota 
Manna Kabupaten Bengkulu

Selatan." Program Studi

Pendidikan Seni Tari Fakultas

Bahasa dan Seni Universitas

Negeri Yogyakarta.

Wawancara. Bustan A. Dali. 13 Februari 2019

Wawancara. Bustan A. Dali. Tais, 20 Juli 2019.

Wawancara. Irwan. Tais, 7 Agustus 2019

Wawancara. Irwan. Tais, 22 Juli 2019.

Wawancara. Jamahari. Sukaraja, 21 Juli 2019.

Wawancara. Rijono. Tais, 22 Juli 2019.

Wawancara. Rijono. Tais, 7 Agustus 2019.

Wawancara. Subur. Dali, 13 Februari 2019.

Wawancara. Yanda. Tais, 19 juli 2019.

Wawancara. Zairin Rasul. Kota Bengkulu, 24 Juli 2019.

Yondri, Rois Leonard Arios, dan Jumhari. 2004. Identifikasi Budaya: Studi Etnografi Suku Bangsa Pekal, di Kecamatan Ketahun, Kabupaten Bengkulu Utara, Propinsi Bengkulu. Padang: Balai Kajian Sejarah dan Nilai Tradisional Padang. 
